\title{
Role of ICT4D in the Growth and Development of SMES : A Solution To Digital Divide
} Masese Chuma Benard, Mbugua Samwel Thaiya, Korongo Julia Nduta, Joram Mutai Kiptoo,

Dr. Nambiro Alice Wechuli

Department of Information Technology, Kibabii University, Kenya

\begin{abstract}
Article Info

Volume 8, Issue 4

Page Number : 294-303

Publication Issue :

July-August-2021

\section{Article History}

Accepted : 20 July 2021

Published: 03 Aug 2021

ICTs have played a critical role within the development of business particularly small and medium enterprises. During a modern digital era, technology is most vital pillar within the provision of data and knowledge for the growth of development, sustainability, productivity and competitiveness of small and medium enterprises. The primary goal of this study was to research on the role of ICT4D in the growth and development of SMEs: a solution to digital divide. The paper used secondary data. It was noted that small and medium enterprises take part in a significant role in Kenya's economy. Enterprises in Kenya, more especially SMEs, have enjoyed the benefits and the potential of adoption and utilization of ICT within their operations. ICT has the potential of remodeling the business and improve.
\end{abstract}

Keywords : ICT, ICT4D, SME'S, Growth and Development, Digital Divide

\section{INTRODUCTION}

The communications revolution and dynamics has encouraged many countries with limited resources to adopt and use ICT for development (ICT4D). This is often enhanced with the adoption of latest technologies like cloud computing, internet of things, block chain, mobile phones, digital computing devices and therefore the network gives the sting and means to unravel the socially, technically and economic development challenges (Chaudhuri, 2012).

ICTs have a crucial role within the community and their proper utilization has proved to possess a big output for socioeconomic development and environmental sustainability especially (Wabwoba
\& Nambiro, 2020).In spite of this developments within the Information Communication and Technology field, small and medium enterprises in third world economies are affected with significant challenges for example slowing down growth, declining trend in technological innovation and adoption, and lack of success of the enterprises(Bunyasi, Bwisa, \& Namusonge, 2014).

In accordance with Kenya Institute for Public Policy Research and Analysis (KIPPRA) study research, noted that small and medium enterprises have finite contribution to the Gross domestic product (GDP) (KIPPRA, 2014). It was further noted that small and medium enterprises contribute up to over sixty percent of the assembly, employment creation and development, but up to seventy to eighty 
percent of the enterprises collapsed (Adeniran \& Johnston, 2012).

Technology is very crucial in the provision of data for the increment of sustainable, productive and competitiveness of small and medium enterprises. Information Communication and Technology utilization in development may be a means, and not an end. Information Communication and Technology may or might not be economical on its own for instance in reducing transaction or transportation budget but it's going to refine development results in nonmonetized layout. It's going to be effortless to account for information communication and technology economic benefits only in direct monetized terms, but on such perspectives, it's going to lack success in determining the opportunity costs (Rahul \& Eswaran, 2006).

The emerging trends in ICTs are getting more available, accessible, and different users can retrieve information from different sources, and a single computing device can meet the requirements of an outsized countryside society. Electronic mail is the most ordinarily used new ICT and has transformed the way people and organizations communicate, in the perspective of time saving, transaction cost and geographical coverage. The world wide web is the second most vital used ICTs, which connects user to access information on many other computers (Justine, Ddembe, \& Venansius, 2004).

Prior research indicated that Information Technology and communication use in small and medium enterprises is slow-moving compare to developed enterprises (Ntwoku, Negash, \& Meso, 2017). Consistent with (AlBar \& Hoque, 2017),the primary impediments to ICT implementation in rural small and medium enterprises are- insufficient top management support, struggle to vary, lack of innovation, inadequate skilled manpower, and a rise within the digital divide between first world economies and third world economies (Apulu, Latham, \& Moreton, 2011).

\section{GROWTH OF THE SMES IN KENYA}

The definition and classification of small businesses tends to vary from country to country basing on each countries' guidelines for categorization. However, it's usually categorized basing on the number of workers and annual income and value of assets (Douglas, Douglas, Muturi, \& Ochieng, 2017). Within the context of this study small and medium enterprises are defined as officially registered business entities, with five to one hundred workers and with per annum turnover of between Kenya Shillings (Kshs) 1,000000 and Kshs 10 million (Mzee, Ogweno, \& Irene, 2015).

(Mochama \& Joseph, 2018) Defines SME growth as; the event process that companies use to take care of a balanced and stable growth or performance level in terms of sales turn over, profit, or revenue. According to (Qureshi S. , 2015) the utilization of ICTs by SMEs facilitate growth, particularly through sustained technology and training interventions.(Qureshi, Kamal, \& Wolcott, 2010) SMEs for example Social Enterprises and NonGovernmental Organizations tend to be closing own the gap and challenges of ICTs on Development. Some scholars have noted that mobile devices and computing devices represent means for the enterprises to get rid of the barriers of buying and selling as they it enhances transmission of information, enable accessibility to market information, global richness to potential clients, do business across the globe without geographic barriers, payment can be done through mobile payment systems (Qureshi S. , 2015).

The uses of mobile phones and computing devices by small and medium enterprises have promoted the performance of small and medium enterprises by improving transparency in business transactions and reducing the unwanted waste of resources (Donner \& Escobari, 2010). 
The micro and small enterprises need to be supported to grow beyond the micro and small level with regard to medium scale enterprises so as to generate more working opportunities, improve its income level, improve the utilization of limited resources, to create opportunities for technological development, such as ICTs (Gikenye, 2014).

Information is an asset for the enterprise creation, growth and survival, more specifically to the modern global business environment where information transmission is instant, and business information especially provides an

honest foundation to remain competitive and gain competitive advantage in business (Gikenye, 2014).

In Kenya, most SMEs operate within the informal sector as family businesses are concentrated in urban centers (Wairimu, 2015). Many SME owners don't own bank accounts, which they consider to be cumbersome, because it would require them to go to banks during critical business hours. For these reasons, mobile money services have grown its popularity among SMEs and unbanked customers. The rapid penetration of mobile telephony has accelerated the usage of mobile banking and mobile money transfer services by SMEs thanks to growth in the total number of consumers using mobile phones (Kiraka, Kobia, \& Katwalo, 2013).

\section{SME SECTORS IN KENYA}

Kenyan government has implemented ICT and internet connectivity to foster socio-economic growth and development through implementing the eCitizen web portal services and customer service centers (Huduma centers) to increase efficiency in electronic-government services done within one roof (Kevin, Sonny, Tigineh, \& Sriram, 2017).

Kenya's national ICT policy objective is to promote the use and access of ICT in rural areas and projecting $80 \%$ access by promoting public and private partnership through usage of a US\$2.89 billion National Broadband Strategy (Samwel M. C., Daoping,
Shaldon, \& Suntu, 2020; Kevin, Sonny, Tigineh, \& Sriram, 2017).

\section{ADOPTION OF ICT4D IN E-BUSINESS}

ICTs have led to more information availability that's easy accessibility (Wabwoba \& Nambiro, 2020).

In reference to the Information Communication and Technology Authority, the ICT sector in Kenya is about US\$500 million worthy that is nine percent of the nation's gross domestic product (GDP) in 2012. Kenya's national ICT policy objective is promoting ICT in rural areas up to $80 \%$ access rate through partnership and therefore the implementation of a US\$2.89 billion National Broadband Strategy (Samwel M. C., Daoping, Shaldon, \& Suntu, 2020).

Computing and mobile device facilitate in the efficient utilization of resources by enterprises. It indicates that 88.1 per cent of the enterprises are using computers in their operations in a daily basis. The internet plays a significant role in accessing and transfer of information, communication, establishing marketing channel in e-business and electronic commerce operations. Further its noted that 81.9 per cent of the companies have internet in their premises and 18.1 per cent of the companies do not have any kind of internet connection in their enterprises (knbs, 2020).

The successful implementation of any ICT project demands that the ICT design and development are aligned with local communities to make sure governance and sustain development outcomes from economic and sociopolitical perspectives (Heeks, 2010). Participative design can play a transparent role in understanding and promoting such a context. Further, there's a requirement for development of frameworks and theories that address the conceptual relationships of ICT innovation alongside communities/other

stakeholders, technical reasoning/institutional dynamics, and sociopolitical context (Lwoga \& Sangeda, 2019; Avgerou, 2010). 


\section{ADOPTION OF E-MARKETING IN SME'S OPERATIONS}

Electronic marketing is a developing trend in the modern globe and many enterprises have implemented the online environment to do business and communicate with their customers. Through the online platform the products information can be published and inventory information is provided by multiple clients and potential customers, whereas transactions are processed by the marketplace operator. Samples of online Market platforms include, eBay, Bid or Buy, OLX \& Deal Fish. These online platforms create a convenience market place to the customer also entices their decisions through discounts and free delivery services (After sales services) (Omoga, 2019).

E-marketing is implementation of network and similar technologies to create, communicate, and deliver value to potential customers (Wilson \& Makau, 2017; Eida \& El-Goharyb, 2013). Introducing webbased marketing requires that decision-makers and electronic marketing specialists to develop new skills. E-marketing creates new opportunities for small and medium enterprises develop and expand their business to the worldwide market place(Mochoge, 2014). In Kenya there are a number of online marketing platform opportunities available to SMEs, such as OLX.co.ke, Cheki.co.ke and Jumia.co.ke (Wilson \& Makau, 2017). The utilization of short message service through Mobile phones and computing devices is of the kind of electronic marketing (Omoga, 2019).

According to Kaur et al. (2015), electronic marketing activities include program marketing, web PR, email marketing, banner advertisements, content marketing, viral marketing, and blog marketing (Kaur, Pathak, \& Kaur, 2015). Electronic marketing is very significant for SMEs to remain operational and thrive in both local and international markets (Alrousan, AlAdwan, Al-Madadha, \& Khasawneh, 2020). Hence, SMEs need to utilize those competitive advantages to improve their chances to remain operational by using online marketing (Wilson \& Makau, 2017).

ICTs enables SMEs to attach to the planet and provides them an environment to develop new business and products. From a marketing view, ICTs provide three main opportunities for SMEs: 1they permit SMEs to implement different digital channels for online marketing purposes;2accessible digital environment to enable marketers to live the marketing performance by collecting, reporting, and processing marketing activities more effectively. 3- it enables SMEs to enhance their performance and growth of its competitiveness in global markets (Alrousan, AlAdwan, Al-Madadha, \& Khasawneh, 2020).

(Wilson \& Makau, 2017) in their study indicated that online marketing use is popularly known to most SMEs. The introduction of online platforms like OLX.co.ke, Cheki.co.ke and Jumia.co.ke are common to most small and medium business owners and clients. However most of the small and medium enterprises do not use full potential of those platforms because most have insufficient IT investment, cannot accommodate IT personnel, lack access thereto constructed infrastructures, some are unaware whether or not there are customers online and status to online payment also as registrations are issues experienced by most SMEs in logging on . The implementation of electronic marketing enhances communication between a firm and potential clients and has led to businesses having a paradigm change in their marketing strategies to market their services. There exist various sorts of E-marketing which enables business processes to be transacted without physical contact between the business partners (Omoga, 2019).

The main advantage of electronic marketing for the enterprises that use it are: rise in exposure to global market places, facilitate communication, and lessen transaction costs thanks to the aggregation of buyers (customers) generated by the e- 
marketplace.

E-marketing results in standardization of products and costs as differences among competitors' products are reduced (Njau \& Karugu, 2014)

\section{ADOPTION OF MOBILE BANKING IN SME'S TRANSACTIONS}

Mobile's phone and hand-held devices have ushered in a change within the social and business lives of the poorest people, in third world economies. Traditionally not have many enterprises possessed landlines or the web, if they stay within the connectivity of a mobile network, they will access information and communicate with friends, family and business contacts (Islama, Habesb, \& Alamc, 2018).

According to (Mochama \& Joseph, 2018) noted that originally, mobile telephones provided voice and digital communication, however, the inclusion of integrated services, like mobile money transfer, Internet and data services have turned them into important tools for transacting business. Attributes like portability and affordability have increased the adoption rate of mobile phones among SMEs. Initially, SMEs had to access banking facilities to transact business or send and receive payments through costly courier services. Of late, this is often not the case because SMEs can conveniently remit or receive payments through mobile money transfer at any time or place and save on costs and time (Mas and Radcliffe, 2010).

According to (Bank, 2012) By the very fact that mobile money services enable SMEs to send and receive money through mobile devices, this has facilitated development to SMEs in informal sector because it promotes services like payments, transfers, mobile wallets and provides linkages between banking and SMEs.
Mobile payments, mobile loans, and mobile banking have an impression on the expansion of SMEs in terms of revenue, savings, sales, and margin of profit. Revenue growth may come from improved business performance thanks to access to financial services - banking, loans, and payment - through mobile money services (Mochama \& Joseph, 2018). the utilization of mobile increased their turnover. the foremost frequently used ICT tool was the mobile (Kiveu, 2013). Mobile phones are used more often for keeping in touch with customers and clients compared to the other sort of communication. Mobile banking is also used by the small and medium enterprises in their operation which helps in simplifying their business activities and providing good services to the customers (Muchiri, 2018). And also revealed that mobile money exhibited to have significant role to the SME industry (Muchiri, 2018). Various studies have indicated a positive impact of mobile and computing devices implementation on enterprise performance, for instance, growth on innovation, attracts more clients, minimize business transportation and transaction times, reduce costs, and reduce storage losses, all of which have led to greater business revenue and profits (Islama, Habesb, \& Alamc, 2018).

In Kenya, Mobile Money service has taken roots, it is used in most business transactions. There are more active Mobile Money accounts than adults within the population (because people can register and use more than one line). It was reported that in 2017 the financial transactions were $\$ 57$ billion, almost three-quarters of the GDP of the country, from $\$ 24$ billion in 2013 (Tengeh \& Talom, 2020).

Banks imposed strict term on credit lending to SMEs since 2008-09 financial crisis, also bank credit sanctioning is time consuming and also not cost 
effective, in additionally strict requirements of collateral (Abbasi, Wang, \& Abbasi, 2017).

Bank credit is often used by small and medium enterprises, though traditional bank funding postures problems to SMEs, especially on start-ups, innovation and fast growth in businesses, with a better risk-return profile and this might also not be suited on different life stage of firm's lifecycle. Besides, banks always need personal guarantor from the proprietor/directors of the SME, which means the proprietor/directors got to risk his personal wealth with a selected end goal to subsidize the organization (Abbasi, Wang, \& Abbasi, 2017).

According to (Mwangi, et al., 2013), there are numerous small and medium enterprises in Kenya which possess great potential but are unable to access financial support from developed institutions within the financial industry. The SMEs possess inadequate loan collateral and also have many operational issues within the SMEs requiring more hands-on assistance than commercial banks and leasing companies.

\section{DIGITAL DIVIDE WITHIN THE BUSINESS SECTOR}

Information technology and communication reduces the knowledge gap by providing rural people a platform for accessing valuable information and transmitting indigenous and country side generated information on different fields (Wabwoba \& Nambiro, 2020). With the rapid development of globalization of the digital economy, information and communication technology (ICT) has transformed business enterprises in developing countries like Kenya (Alrawabdeh, Salloum, \& Mingers, 2012).

Information communication and technology is an important partner in bridging the gap between business enterprises in developing and developed countries. Moreover, it also plays an important part in reducing the gap between the enterprises in urban and rural areas in developing countries (ITU, 2011). The small and medium enterprises can make more efficient, competitive and innovative decisions through the utilization of ICT. Electronic business involves purchase or sale of products and services and delivery through the online platform also receiving of payment through mobile money transactions (knbs, 2020).

It has been noted from the existing literature that a number of studies have been conducted on the utilization, impact, adoption and diffusion of ICT by SMEs. Some scholars have attempted to spot the factors that influence the adoption and utilization of ICT among SMEs. Other researches have indicated that the adoption and utilization of ICT by SMEs remains less than expected. Some of the barriers, like limited data about ICT, inadequate support from the state, limited investment in ICT infrastructure, finite support from banks and management problems, are identified as causes of the low adoption of ICT by SMEs (Adnan \& Rakibu, 2017).

\section{PROBLEM STATEMENT}

The United Nations 2030 Agenda for Sustainable Development encourages ICTs and international connectivity as accelerators of sustainable development (ITU, 2018). ICT is used in various sectors as a facilitating tool for the implementation of Sustainable Development Goals (SDGs) and acts as a catalyst for the three pillars of sustainable development that is economic, social and environmental development (Chege \& Wang, 2020). In Kenya the utilization of Internet Service Providers (ISPs) raised by 18.0 per cent from 256 in 2018 to 302 in 2019. This rise is attributed to the growth in demand for fiber optic internet connection by people and enterprises. Also fixed broadband specifically the fiber optic has continued to 
grow within the last four years that is facilitated by its growing preference among enterprises (knbs, 2020). But there has been finite literature on topics relating to: 1 - The adoption and usage of ICTs and 2to what percentage has enhanced the expansion and development of SME'S in rural SMEs in Kenya. there's great concern to know the linkages between ICT and development. This paper has been undertaken to reduce the existing literature gap.

\section{METHODOLOGY}

This paper used qualitative research approaches. The paper trusted secondary data that were obtained from other related studies that were published online. They were retrieved and therefore the supported their relevance to the theme of this paper.

\section{CONCLUSION}

The main objective of this paper was to research on the role of ICT4D within the growth and development of SMEs: a solution to digital divide. Small and medium enterprises play a critical part in Kenya's economy. Business in Kenya, more especially SMEs, have enjoyed the advantages of adoption of ICT within the operations. Thus, SMEs can retain a competitive advantage by implementing ICT innovation and development within growth of the enterprises. The SMEs operate during a competitive environment ICT has the potential of remodeling the business and improve its performance both internally and externally developing an honest relationship and understanding with different stakeholders just like the government, customers, suppliers, partners and business.

\section{REFERENCES}

[1]. Abbasi, W. A., Wang, Z., \& Abbasi, D. A. (2017). Potential Sources of Financing for Small and Medium Enterprises (SMEs) and Role of Government in Supporting SMEs. Journal of Small Business and Entrepreneurship Development, 39-47.

[2]. Adeniran, T., \& Johnston, K. (2012). Investigating the level of internet capabilities of South African small and medium enterprises in changing environments. African Journal of Business Management, 4088-4099.

[3]. Adnan, M. A., \& Rakibu, 1. H. (2017). Factors affecting the adoption of information and communication technology in small and medium enterprises: a perspective from rural Saudi Arabia. Information Technology for Development, 1-24.

[4]. AlBar, A. M., \& Hoque, M. R. (2017). Factors affecting the adoption of information and communication technology in small and medium enterprises: A perspective from rural Saudi Arabia. Information Technology for Development, 1-24.

[5]. Alrousan, M. K., Al-Adwan, A. S., Al-Madadha, A., \& Khasawneh, M. H. (2020). Factors Affecting the Adoption of E-Marketing by Decision Makers in SMEs:Evidence From Jordan. International Journal of E-Business Research, 1-27.

[6]. Apulu, I., Latham, A., \& Moreton, R. (2011). Factors affecting the effective utilisation and adoption of sophisticated ICT SOLUTIONS. Journal of Systems and Information Technology, 125-143.

[7]. Avgerou, C. (2010). Discourses on ICT and development. Information Technologies \& International Development, , 1-18.

[8]. Bank, W. (2012). Information and communications for development 2012: 
Maximizing mobile. Washington, DC: World Bank.

[9]. Bunyasi, G. N., Bwisa, H., \& Namusonge, G. (2014). Effect of access to business information on the growth of small and medium enterprises in Kenya. International Journal of Business and Social Science, 121-128.

[10]. Chaudhuri, A. (2012). ICT for Development: solutions seeking problems? Journal of Information Technology , 326-338.

[11]. Chege, S. M., \& Wang, D. (2020). The influence of technology innovation on SME performance through environmental sustainability practices in Kenya. Technology in Society.

[12]. Donner, J., \& Escobari, M. X. (2010). A review of evidence on mobile use by micro and small enterprises in developing countries. Journal of International Development, 641-658.

[13]. Douglas, J., Douglas, A., Muturi, D., \& Ochieng, J. (2017). An exploratory study of critical success factors for SMEs in Kenya. 20th Excellence in Services International Conference, (pp. 223-234). University of Verona -Verona (Italy).

[14]. Eida, R., \& El-Goharyb, H. (2013). the impact of e-marketing use on small business enterprises'marketing success. Service Industries Journal, 31-50.

[15]. Gikenye, W. (2014). The status and development of informal sector and ICT access in Kenya. Inkanyiso, Journall Humunities \& Social Sciences, 77-88.

[16]. Islama, M., Habesb, E. M., \& Alamc, M. (2018). The usage and social capital of mobile phones and their effect on the performance of microenterprise: An empirical study $\boldsymbol{r}^{2}$. Technological Forecasting \& Social Change, 156-14.

[17]. ITU. (2018). Achieving universal and affordable internet in the least developed countries. geneva, switzerland.
[18]. Justine, K., Ddembe, W., \& Venansius, B. (2004). The Role of ICTs and their Sustainability In. Sustainable Information and Communication Technology Development Developing Countries, 78-88.

[19]. Kaur, P., Pathak, \& Kaur, K. (2015). EMarketing- A Global Perspective. International Journal of Engineering Research and Applications, 116-124.

[20]. Kevin, I., Sonny, N., Tigineh, M., \& Sriram, V. (2017). Digital Kenya. An entrepreneurial revolution in the making.In N. Bitange \& W. Tim (Eds.). The Palgrave studies of entrepreneurship in Africa series, 1-518.

[21]. KIPPRA. (2014). Navigating global challenges while exploiting opportunities for sustainable growth. Nairobi. Kenya Institute for Public Policy Research and Analysis (KIPPRA).

[22]. Kiraka, R. N., Kobia, M., \& Katwalo, A. M. (2013). Micro, small and medium enterprise growth and innovation inKenya: A case study on the women enterprise fund. Nairobi, Kenya: Kenya Investment Climate and Business Environment Research Fund Research.

[23]. Kiveu, M. N. (2013). DETERMINANTS OF ICT ADOPTION AND USE BY SMALL AND MEDIUM ENTERPRISES: THE CASE OF SMES IN THIKA MUNICIPALITY, KENYA. INTERNATIONAL JOURNAL OF ADVANCED RESEARCH, 717-726.

[24]. knbs. (2020). Economic Survey. nairobi: Kenya National Bureau of Statistics.

[25]. Lwoga, E. T., \& Sangeda, R. Z. (2019). ICTs and development in developing countries: A systematic review of reviews. E J Info Sys Dev Countries.wileyonlinelibrary.com/journal/isd2, 1-17.

[26]. Mochama, J. B., \& Joseph, F. N. (2018). EFFECT OF MOBILE MONEY TRANSFER SERVICES ON THE GROWTH OF SMALL AND MEDIUM ENTERPRISES IN INFORMAL SECTOR OF NAIROBI COUNTY, KENYA. 
International Journal of Information Research and Review, 5326-5333.

[27]. Mochoge, O. C. (2014). SMES' ADOPTION OF WEB-BASED MARKETING:EMPIRICAL EVIDENCE FROM KENYA. IJCSI International Journal of Computer Science Issues, 226-236.

[28]. Muchiri, J. W. (2018). EFFECT OF MOBILE BANKING ADOPTION ON THE PERFORMANCE OF SMALL AND MEDIUM ENTERPRISES IN NAIROBI COUNTY. International Journal of Economics, Business and Management Research, 445-486.

[29]. Mwangi, M., George, G. E., Mindila, R., Nyakwara, S., Ongeri, J., \& Okeyo, H. N. (2013). An Evaluation of Financing and Development of Small and Medium Enterprises in Mombasa County, Kenya. European Journal of Business and Management, 16-25.

[30]. Mzee, R. M., Ogweno, K. L., \& Irene, N. (2015). Factors influencing Adoption of $\mathrm{E}$ marketing by small and Medium Enterprises (SMEs) in Kisumu Municipality. IOSR Journal of Business and Management (IOSR-JBM), 78-83.

[31]. Njau, J. N., \& Karugu, W. (2014). INFLUENCE OF E-MARKETING ON THE PERFORMANCE OF SMALL AND MEDIUM ENTERPRISES IN KENYA: SURVEY OF SMALL AND MEDIUM ENTERPRISES IN THE MANUFACTURING INDUSTRY IN KENYA. International Journal of Business \& Law Research, 62-70.

[32]. Ntwoku, H., Negash, S., \& Meso, P. (2017). ICT adoption in Cameroon SME: Application of bass diffusion model. Information Technology for Development, 296-317.

[33]. Omoga, C. O. (2019). Challenges in EMarketing Adoption Among Small Businesses in the Hospitality Industry in Kenya. International Journal of Advanced Research in Computer and Communication Engineering, 229-235.

[34]. Qureshi, S. (2015). Are we making a Better World with Information and Communication
Technology for Development (ICT4D) Research? Findings from the Field and Theory Building. Information Technology for Development, 511-522.

[35]. Qureshi, S., Kamal, M., \& Wolcott, P. (2010). Information technology interventions for growth and competitiveness in microenterprises. In P. Bharati, I. Lee, \& A. Chaudhury (Eds.), Global perspectives on small and medium enterprises and strategic information systems: International approaches, 306-329.

[36]. Rahul, T., \& Eswaran, S. (2006). Information and Communications Technology for Development (ICT4D) - A Design Challenge? 202 (paper submission number) - ICTD.

[37]. Samwel, M. C., Daoping, W., \& Shaldon, L. S. (2020). Impact of information technology innovation on firm performance in Kenya. Information Technology for Development, 316-345.

[38]. Samwel, M. C., Daoping, W., Shaldon, \& Suntu, L. (2020). Impact of information technology innovation on firm performance in Kenya. INFORMATION TECHNOLOGY FOR DEVELOPMENT, 316-345.

[39]. Tengeh, R. K., \& Talom, F. S. (2020). Mobile Money as a Sustainable Alternative for SMEs in Less Developed Financial Markets. Journal of Open Innovation Technology. Markert Complexity, 1-21.

[40]. Wabwoba, F., \& Nambiro, A. W. (2020). ICT for Sustainable Development without Digital Divide in Africa Digital Divide in Africa. International Journal of Computer Trends and Technology (IJCTT), 77-80.

[41]. Wairimu, W. W. (2015). Micro, small and medium-size enterprises (MSMEs) as suppliers to the extractive industry. Nairobi, Kenya: UNDP-Kenya.

[42]. Wilson, V., \& Makau, C. (2017). ONLINE MARKETING USE: SMALL AND MEDIUM 
ENTERPRISES (SMES) EXPERIENCE FROM

KENYA. ORSEA Journal, 63-77.

\section{Cite this article as :}

Masese Chuma Benard, Mbugua Samwel Thaiya, Korongo Julia Nduta, Joram Mutai Kiptoo, Dr. Nambiro Alice Wechuli, "Role of ICT4D in the Growth and Development of SMES : A Solution To Digital Divide", International Journal of Scientific Research in Science, Engineering and Technology (IJSRSET), Online ISSN : 2394-4099, Print ISSN : 2395-1990, Volume 8 Issue 4, pp. 294-303, JulyAugust 2021. Available at doi : https://doi.org/10.32628/IJSRSET218440 